Program Studi Agroteknologi, Universitas Ma'arif Nahdlatul Ulama Kebumen

\title{
ANALISIS USAHA TANI BUDIDAYA TANAMAN JAGUNG DI DESA BOCOR, KECAMATAN BULUSPESANTREN KABUPATEN KEBUMEN
}

\author{
Riski Utomo ${ }^{\text {a }}$, Umi Barokah ${ }^{\mathrm{b}}$, Aulia Rahmawati ${ }^{\mathrm{c}}$ \\ ${ }^{\text {a }}$ Mahasiswa Agroteknologi, Universitas Ma'arif Nahdlatul Ulama Kebumen \\ ${ }^{\mathrm{b}, \mathrm{c}}$ Dosen Agroteknologi, Universitas Ma'arif Nahdlatul Ulama Kebumen \\ $\underline{\text { riskiutomo07@gmail.com }}^{\text {a }}, \underline{\text { barokahumi@yahoo.com }}^{\text {b }}$ awliarahmawati@gmail.com $^{\text {c }}$
}

\begin{abstract}
ABSTRAK
Penelitian ini bertujuan untuk mengetahui (1) besarnya penerimaan dan pendapatan petani dalam budidaya tanaman jagung selama satu musim tanam, (2) besarnya $\mathrm{R} / \mathrm{C}$ usaha jagung dalam satu kali musim tanam. Hal ini dilakukan karena banyak petani yang belum melakukan analisa usaha tani untuk mengetahui hasil keuntungan atau kerugian budidaya tanaman jagung mulai dari biaya alat penunjang budidaya, biaya sarana produksi, dan biaya tenaga kerja yang dibutuhkan. Petani di Desa Bocor, Kecamatan Buluspeseantren, Kabupaten Kebumen khususnya daerah sawah tegalan mampu menanam dua kali musim tanam dalam satu tahun. Terlebih beberapa tahun ini harga jual jagung pipil kering mampu menembus harga 5000/kg. Penelitan ini dilakukan dengan metode wawancara secara langsung kepada satu orang petani jagung. Wawancara ini dilakukan dengan tujuan untuk memperoleh data yang nyata tentang biaya yang dibutuhkan petani untuk budidaya tanaman jagung dalam satu musim tanam. Hasil penelitian ini menunjukan bahwa biaya total untuk satu kali musim tanam sebesar Rp 20.445.002,- untuk penerimaan sebesar Rp 39.150.000,- sehingga didapat nilai pendapatan sebesar Rp 18.704.978,-. Besarnya R/C pada usaha tani jagung satu kali musim tanam per hektar adalah 1,91 artinya setiap $\mathrm{Rp} \mathrm{1,-}$ biaya yang dikeluarkan akan memperoleh penerimaan sebesar $\mathrm{Rp}$ 1,91,- dan pendapatan sebesar Rp 0,91,-. Analisis usaha budidaya tanaman jagung menunjukan bahwa usaha tani tersebut menguntungkan dan layak untuk diusahakan karena R/C > 1 yaitu 1,91 .
\end{abstract}

Kata kunci : Budidaya, Jagung, Modal

\begin{abstract}
This study aims to determine (1) the amount of income and income of farmers in the cultivation of corn during one growing season, (2) the amount of $R / C$ of corn business in one growing season. This is done because many farmers have not done farming analysis to find out the profit or loss of corn cultivation starting from the cost of cultivation support equipment, the cost of production facilities, and the cost of the required labor. Farmers in Bocor Village, Buluspeseantren Sub-district, Kebumen Regency, especially in upland areas are able to plant two planting seasons in one year. Moreover, in recent years the selling price of dry shelled corn
\end{abstract}



has been able to penetrate the price of 5000/kg. This research was conducted by interview method directly to one corn farmer. This interview was conducted with the aim of obtaining real data about the costs needed by farmers to cultivate corn in one growing season. The results of this study indicate that the total cost for one planting season is $R p$. 20,445,002, - for revenue of $R p$. 39,150,000, - so that the income value is $R p .18,704,978$. The amount of $R / C$ in corn farming once a planting season per hectare is 1.91, meaning that for every Rp. 1,- the costs incurred will receive an income of Rp. 1.91,- and an income of Rp. 0.91.-. The analysis of the corn cultivation business shows that the farming is profitable and feasible because the $R / C>1$ is 1.91 .

Keywords: Cultivation, Corn, Capital

\section{PENDAHULUAN}

Indonesia dikenal sebagai negara agraris yang berarti negara yang mengandalkan sektor pertanian sebagai mata pencaharian maupun sebagai penopang pembangunan. Sektor pertanian merupakan penopang perekonomian di Indonesia karena pertanian membentuk proporsi yang sangat besar memberikan sumbangan untuk kas pemerintah. Hal ini kemudian menjadikan sektor pertanian sebagai pasar yang potensial bagi produk-produk dalam negeri baik untuk barang konsumsi, terutama produk yang dihasilkan oleh sub sektor tanaman pangan (Rodo Berliana, 2010).

Salah satu komoditas pangan yang memiliki arti penting baik bagi masyarakay maupun pemerintah Indonesia adalah jagung (Zea mays L.). Keunggulan jagung dibanding komoditas pangan lain adalah kandungan gizinya yang hampir sama dengan beras sehingga memadai untuk dijadikan makanan pokok sebagai pengganti beras atau dicampurkan dengan beras. Jagung merupakan salah satu bahan pangan penting karena merupakan sumber karbohidrat penting kedua setelah beras di Indonesia (Apriani et al., 2016).

Jagung selain digunakan sebagai olahan makanan juga dimanfaatkan sebagai bahan baku industri etanol dan pakan ternak. Oleh sebab itu, potensi jagung sangat besar dilakukan oleh petani sebagai salah satu budidaya tanaman. Jagung salah satu komoditas pangan utama yang ditargetkan oleh kementrian pertanian mencapai swasembada pada tahun 2014 dengan produksi 29 juta ton. (Marwoto Hari, 2018).

Subsektor tanaman pangan komoditas palawija terbagi menjadi beberapa tanaman, salah satunya tanaman jagung. Angka tetap hasil sensus pertanian 2013 menunjukan jumlah rumah tangga usaha pertanian tanaman jagung sebesar 5.057.532 rumah tangga dengan persentase sebesar persen. Tanaman jagung memiliki luas tanam sebesar $21.614 .905 .939 \mathrm{~m} 2$ dengan ratarata luas tanam sebesar 4.274. (Badan Pusat Statistik, 2013).

Tabel 1. Target Kinerja Ditjen Tanaman Pangan Tahun 2020-2024

\begin{tabular}{ccccccc}
\hline Sasaran & satuan & 2020 & 2021 & 2022 & 2023 & 2024 \\
\hline $\begin{array}{c}\text { Peningkatan } \\
\text { produksi } \\
\text { jagung }\end{array}$ & $\%$ & 24.60 & 3.24 & 3.45 & 3,33 & 3.52 \\
& & & & & & \\
\hline
\end{tabular}


Program Studi Agroteknologi, Universitas Ma'arif Nahdlatul Ulama Kebumen

Kebumen merupakan salah satu kabupaten di Jawa Tengah yang terletak di pesisir selatan. Secara geografis daerah Kebumen dapat dibedakan menjadi tiga kawasan yaitu kawasan pegunungan di utara, pantai di selatan dan daerah tengah. Desa Bocor Kecamatan Buluspesantren terletak $10 \mathrm{~km}$ selatan Kota Kebumen (Romadi, 2010). Desa Bocor merupakan daerah kawasan pantai. Di daerah ini banyak petani yang membudidayakan jagung.

Banyaknya petani yang membudidayakan tanaman jagung, namun petani tersebut jarang yang melakukan analisi usaha tani tanaman jagung. Petani dalam berusaha tani harus memperhitungkan biaya yang dikeluarkan, penerimaan yang mereka terima, keuntungan yang diperoleh dan efisiensi dari usaha taninya (Noviana,2003). Penelitian dilakukan dengan tujuan untuk mengetahui besarnya penerimaan dan pendapatan petani jagung selama budidaya tanaman jagung, Petani juga dapat mengetahui besarnya R/C pada usaha tani jagung.

\section{METODOLOGI PENELITIAN}

Penelitian ini telah dilakukan pada bulan Juli sampai Oktober 2021 di dukuh Pedati, Desa Bocor, Kecamatan Buluspesantren, Kabupaten Kebumen. Dalam hal ini penelitian dilakukan dengan metode wawancara dan survei langsung ke petani jagung dengan jumlah narasumber satu orang. Pertanyaan yang diajukan seputar komponen alat dan bahan serta upah harian untuk tenaga kerja. Selain itu, juga melakukan pengajuan pertanyaan seputar budidaya dari persiapan lahan, penanaman, perawatan, pengendalian hama dan penyakit, pemupukan, panen, serta perlakuan pasca panen tanaman jagung. Analisis data dilakukan dalam satu kali musim tanam mulai dari proses pengolahan tanah sampai penanganan pasca panen selama empat bulan. Hasil dari wawancara nantinya disajikan menggunakan tabel untuk memudahkan penyampaian informasi.

\section{HASIL DAN PEMBAHASAN}

Ilmu usaha tani biasanya diartikan sebagai ilmu yang mempelajari bagaimana seorang mengalokasikan sumberdaya yang ada secara efektif dan efisien untuk tujuan memperoleh keuntungan yang tinggi pada waktu tertentu. Berdasarkan dari hasil penelitian yang dilakukan dengan metode survei dan wawancara menemukan beberapa catatan, diantaranya ada modal peralatan, saprodi, dan tenaga kerja. Selain itu, peneliti dalam menjelaskan dengan tabel langsung menggunakan ukuran ha.

Tabel 2. biaya permodalan dan biaya penyusutan usaha tani jagung

\begin{tabular}{llcrrrrrr}
\hline No. & Uraian & Jumlah & Satuan & $\begin{array}{c}\text { Harga/satuan } \\
(\mathbf{R p})\end{array}$ & $\begin{array}{c}\text { Total } \\
(\mathbf{R p})\end{array}$ & $\begin{array}{c}\text { Umur } \\
\text { Ekonomis } \\
\text { (tahun) }\end{array}$ & Nilai Sisa & $\begin{array}{c}\text { Penyusutan } \\
(\mathbf{R p})\end{array}$ \\
\hline A & ALAT & & & & & & & \\
\hline 1 & Cangkul & 14 & buah & $200,000.00$ & $2,800,000.00$ & 5 & $350,000.00$ & $163,333.33$ \\
\hline 2 & Alat tugal & 4 & buah & $20,000.00$ & $80,000.00$ & 10 & $6,000.00$ & $2,466.67$ \\
\hline 3 & Gerobak arco & 3 & buah & $450,000.00$ & $1,350,000.00$ & 5 & $300,000.00$ & $70,000.00$ \\
\hline 4 & Ember & 7 & buah & $19,000.00$ & $133,000.00$ & 2 & $17,500.00$ & $19,250.00$ \\
\hline 5 & Pompa air & 2 & buah & $3,500,000.00$ & $7,000,000.00$ & 3 & $850,000.00$ & $683,333.33$ \\
\hline 6 & Selang & 8 & buah & $50,000.00$ & $400,000.00$ & 2 & $40,000.00$ & $60,000.00$ \\
\hline
\end{tabular}


Program Studi Agroteknologi, Universitas Ma'arif Nahdlatul Ulama Kebumen

\begin{tabular}{rlrrrrrrr}
7 & Tali benang & 2 & roll & $35,000.00$ & $70,000.00$ & 2 & $20,000.00$ & $8,333.33$ \\
\hline 8 & handsprayer & 2 & buah & $650,000.00$ & $1,300,000.00$ & 4 & $200,000.00$ & $91,666.67$ \\
\hline 9 & Terpal & 50 & buah & $35,000.00$ & $1,750,000.00$ & 2 & $100,000.00$ & $275,000.00$ \\
\hline 10 & Karung & 70 & buah & $2,500.00$ & $175,000.00$ & 2 & $35,000.00$ & $23,333.33$ \\
\hline 11 & Sabit & 7 & buah & $50,000.00$ & $350,000.00$ & 3 & $52,500.00$ & $33,055.56$ \\
\hline & & & Jumlah & & & $1,429,772.22$ \\
\hline
\end{tabular}

Dari tabel diatas dapat dijelaskan bahwa permodalan alat merupakan modal utuh yang bisa dipakai untuk kemudian hari. Namun setiap peralatan memiliki nilai penyusutan harga. Nilai penyusutan alat adalah besarnya korbanan ekonomis yan harus diperhitungkan setiap tahun dari alat produksi tahan lama selama proses produksi (Rp per proses produksi) (Suratiyah, 2006). Biaya penyusutan alat produksi merupakan biaya tetap yang besarnya tidak bergantung pada besar kecilnya biaya yang diperoleh. Biaya tetap (fixed cost) adalah biaya yang relative jumlahnya dan terus dikeluarkan walaupun produksi yang diperoleh banyak atau sedikit. Dihitung dengan rumus : (Nilai total - Nilai sisa)/ (umur ekonomis * 12(jumlah bulan satu tahun)* 4 (umur tanaman jagung dalam bulan). Diantara penyusutan barang atau alat adalah:

1. Cangkul harga awal 2800000 menjadi 163333.

2. Alat tugal harga awal 80000 menjadi 2467.

3. Gerobak arco harga awal 1350000 menjadi 70000.

4. Ember harga awal 13300 menjadi 19250.

5. Pompa air harga awal 7000000 menjadi 683333.

6. Selang harga awal 400000 menjadi 60000.

7. Tali benang harga awal 70000 menjadi 8333 .

8. Hansprayer harga awal 1300000 menjadi 91667.

9. Terpal harga awal 17500000 menjadi 275000.

10. Karung harga awal 175000 menjadi 23333.

11. Sabit harga awal 350000 menjadi 33056.

Tabel 3. Tabel sarana produksi budidaya tanaman jagung.

\begin{tabular}{llccrr}
\hline B & SAPRODI & Jumlah & Satuan & $\begin{array}{c}\text { Harga/satuan } \\
(\mathbf{R p})\end{array}$ & \multicolumn{1}{c}{ Total (Rp) } \\
\hline 1 & Benih & 17 & $\mathrm{Kg}$ & $105,000.00$ & $1,785,000.00$ \\
\hline 2 & Tanah & 1 & $\mathrm{Ha}$ & $3,200,000.00$ & $3,200,000.00$ \\
\hline 3 & Pestisida & 1 & liter & $167,500.00$ & $117,250.00$ \\
\hline 4 & Herbisida Gramoxone & 3 & liter & $70,000.00$ & $210,000.00$ \\
\hline 5 & Herbisida Selektif & 7 & paket & $80,000.00$ & $560,000.00$ \\
\hline 6 & BBM & 120 & liter & $7,650.00$ & $918,000.00$ \\
\hline 7 & Urea & 350 & Kg & $2,240.00$ & $784,000.00$ \\
\hline 8 & NPK & 350 & Kg & $2,300.00$ & $805,000.00$ \\
\hline 9 & Pupuk kandang & 35 & zak & $10,000.00$ & $350,000.00$ \\
\hline & & Jumlah & & & $8,729,250.00$ \\
\hline
\end{tabular}


Penjelasan diatas memberikan kesimpulan bahwa setiap alah memiliki nilai susut yang berbeda tergantung umur dan kegunaan barang tersebut.Untuk sarana produksi merupakan barang satu kali pakai, dimana penggunaanya hanya satu kali pakai saja. Sarana produki juga memiliki nilai susut seperti peralatan pada tabel nomor satu. Bisa dijelaskan bahwa satu musim tanam jagung pada lahan satu hektar adalah:

1. Benih membutuhkan $17 \mathrm{~kg}$ dengan harga total Rp. 1785000.

2. Tanah membutuhkan 1 ha dengan sewa harga Rp. 3200000.

3. Pestisida membutuhkan 1 liter dengan harga Rp. 117250.

4. Herbisida gramaxone membutuhkan 3 liter dengan harga Rp. 210000.

5. Herbisida selektif membutuhkan 7 paket dengan harga Rp. 560000.

6. BBM membutuhkan 120 liter dengan harga Rp. 918000.

7. Urea membutuhkan $350 \mathrm{~kg}$ dengan harga Rp. 784000.

8. NPK membutuhkan $350 \mathrm{~kg}$ dengan harga Rp. 805000.

9. Pupuk kandang membutuhkan 35 zak dengan harga Rp. 350000.

Tabel 4. Biaya Operasional Budidaya Tanaman Jagung di Desa Bocor, Kecamatan Buluspesantren, Kabupaten Kebumen

\begin{tabular}{llccr}
\hline C & \multicolumn{1}{c}{ Tenaga kerja } & $\begin{array}{c}\text { Satuan Harga } \\
(\mathrm{Rp})\end{array}$ & $\begin{array}{c}\text { Jumlah } \\
\text { HOK }\end{array}$ & $\begin{array}{c}\text { Jumlah } \\
\text { Total }\end{array}$ \\
\hline 1 & Penyiapan lahan tanam & $70,000.00$ & 2 & $140,000.00$ \\
\hline 2 & Pembuatan larikan dan lubang tanam & $70,000.00$ & 21 & $1,470,000.0$ \\
\hline 3 & Penanaman & $60,000.00$ & 10 & $600,000.00$ \\
\hline 4 & Pemupukan dasar & $70,000.00$ & 2 & $140,000.00$ \\
\hline 5 & Penyiraman & $70,000.00$ & 9 & $630,000.00$ \\
\hline 6 & Penyemprotan gulma(herbisida) & $70,000.00$ & 2 & $140,000.00$ \\
\hline 7 & Pemupukan & $70,000.00$ & 7 & $490,000.00$ \\
\hline 8 & Pembumbunan & $70,000.00$ & 14 & $980,000.00$ \\
\hline 9 & Pengendalian hama penyakit & $70,000.00$ & 10 & $700,000.00$ \\
\hline 10 & Panen & $70,000.00$ & 28 & $1,960,000.0$ \\
\hline 11 & Penggilingan & & & $1,566,000.0$ \\
\hline
\end{tabular}

Biaya operasional juga dapat dikatakan sebagai biaya produksi. Biaya produksi dapat di bagi menjadi dua yaitu biaya-biaya yang berupa uang tunai misalnya upah kerja untuk biaya persiapan/penggarapan, tanah termasuk upah untuk ternak, biaya untuk membeli pupuk dan pestisida, dan lain-lain. Besar kecilnya bagian biaya produksi yang berupa uang tunai ini sangat mempengaruhi pengembangan usaha tani. Tabel ini menjelaskan tentang upah harian atau yang dikeluarkan selama budidaya tanaman jagung dari persiapan lahan sampai penanganan pasca panen. Untuk harga satuan atau harian ditentukan dengan harga asli di tempat penelitian. Diantaranya dana yang dikeluarkan selama budidaya tanaman jagung sebagai berikut: 
Program Studi Agroteknologi, Universitas Ma'arif Nahdlatul Ulama Kebumen

1. Penyiapan lahan membutuhkan 2 HOK dengan nilai harga Rp. 140000.

2. Pembuatan larikan dan lubang tanam 21 HOK dengan nilai harga Rp .1470000.

3. Penanaman 10 HOK dengan nilai harga Rp. 600000.

4. Pemupukan dasar 2 HOK dengan nilai harga Rp. 140000.

5. Penyirama 9 HOK dengan nilai harga Rp. 630000.

6. Penyemprotan gulma 2 HOK dengan nilai harga Rp. 140000.

7. Pemupukan 7 HOK dengan nilai harga Rp. 490000.

8. Pembumbuman membutuhkan 14 HOK dengan nilai harga Rp. 980000.

9. Pengendalian hama penyakit membutuhkan $10 \mathrm{HOK}$ dengan nilai harga Rp. 700000.

10. Panen membutuhkan 28 HOK dengan nilai harga Rp. 196000.

11. Penggilingan membutuhkan biaya Rp. 1566000.

12. Penjemuran membuthkan 21 HOK dengan nilai harga Rp. 1470000.

\subsection{Penerimaan usaha tani jagung}

Hasil panen yan diperoleh dari proses produksi adalah 7830 kilogram, dengan harga jual perkilo adalah $\mathrm{Rp} 5.000$,- maka penerimaan usaha tani jagung per satu kali proses produksi adalah Rp 39.150.000,-. Besarnya penerimaan usaha tani jagung sangat dipengaruhi oleh jumlah produksi dan harga yang diterima petani. Walaupun produksi yang dihasilkan petani tinggi, sering kali harga yang diterima petani rendah, sehingga menyebabkan kerugian dalam usaha taninya (Heriani et al., 2013).

\subsection{Pendapatan usaha tani jagung}

Harga dan pendapatan dari produksi dapat mempengaruhi usaha tani sehingga perlu dalam analisis usaha tani (Luntungan, 2015). Pendapatan adalah selisih antara penerimaan dan biaya total. Hal ini didukung oleh Pata (2011) bahwa keuntungan merupakan pendapatan yang diperoleh petani dari usaha tani tomat yang dapat diketahui dari selisih antara penerimaan total dan biaya total. Diketahui sebelumnya bahwa biaya total Rp 20.445.022,- dan penerimaan Rp 39.150.000,- sehingga pendapatan dari usaha tani jagung per satu kali musim tanam Rp 18.704.978,-. Peningkatan pendapatan usaha tani jagung dapat meningkatkan kesejahteraan petani dan keluarganya. Pendapatan yang diterima biasanya digunakan untuk membiayai kehidupan sehari-hari, selain itu apabila ada saja pendapatan yang tidak habis digunakan dalam membiayai kebutuhannya maka sisa dana tersebut akan di gunakan untuk investasi atau tabungan.

\subsection{Analisis ratio}

$\mathrm{R} / \mathrm{C}$ adalah perbandingan antara penerimaan dengan biaya produksi. Diketahui penerimaan sebesar $\mathrm{Rp} 39.150 .000$,- dan biaya produksi sebesar Rp 20.445.022,- maka R/C usaha tani jagung digunakan rumus menurut (Suratiyah,2006).

$R / C=\frac{39.150 .000}{20.445 .022}$

$R / C=1,9$ 
Program Studi Agroteknologi, Universitas Ma'arif Nahdlatul Ulama Kebumen

Hasil penelitian menunjukkan nilai R/C atas biaya total yaitu sebesar 1,9 atau lebih dari 1. Hal ini berarti usaha tani jagung yang dilakukan oleh petani di Desa Bocor, Kecamatan Buluspesantren, Kabupaten Kebumen secara ekonomi menguntungkan dan layak diusahakan. Secara teoritis kenaikan pendapatan akan bertambah pula jumlah biaya. Dengan adanya kenaikan tingkat pendapatan ini secara tidak langsung akan menambah pendapatan negara pada umumnya dan sekaligus dengan kenaikan pendapatan ini akan menunjang pembangunan desa, daerah dan nasional, karena dengan pendapatannya maka petani mempunyai kemungkinan dan kesempatan yang lebih banyak untuk berpartisapasi dalam pembangunan.

\section{KESIMPULAN}

Nilai penerimaan dari hasil produksi jagung satu kali musim tanam adalah sebesar Rp 39.150.000,-. Nilai pendapatan dari hasil produksi jagung satu musim tanam adalah sebesar Rp 18.704.978,- Besarnya nilai $\mathrm{R} / \mathrm{C}$ usaha tani jagung selama satu musim tanam adalah 1,91. Artinya setiap Rp 1,- biaya yang dikeluarkan akan memperoleh penerimaan sebesar Rp 1,91. dan nilai pendapatan sebesar Rp 0,91. Berdasarkan hasil analisis usaha budidaya tanaman jagung menunjukan bahwa usaha tani tersebut menguntungkan dan layak untuk diusahakan karena $\mathrm{R} / \mathrm{C}>1$ yaitu 1,91 .

\section{DAFTAR PUSTAKA}

Apriani, A.E., Soetoro., \& Yusuf, M.N. (2016). Analisis usaha tani jagung (Zea mays L.) (suatu kasus di Desa Pancawangi Kecamatan Pancatengah Kabupaten Tasikmalaya). Jurnal Ilmiah Mahasiswa AGROINFO GALUH, 2(3), 145-150

Badan Pusat Statistik. (2013). Sensus Pertanian. Indonesia.

Berliana, Rodo. (2010). Analisis Efisiensi Produksi dan Pendapatan pada Usaha tani Jagung (Kasus Desa Tambahreja dan Desa tambselo, Kecamatan Wirosari, Grobogan [Skripsi]. Semarang: Fakultas Ekonomi, Universitas Diponegoro.

Direktorat Jendral Tanaman Pangan. (2020). Rencana Strategis. Jakarta.

Heriani, N., Zakaria, W.A. \& Soelaiman, A. (2013). Analisis keuntungan dan risiko usaha tani tomat di Kecamatan Sumberejo Kabupaten Tanggamus. JIIA, 1(2), 169-173

Luntungan, A.Y. (2015). Analisis tingkat pendapatan usaha tani tomat apel di Kecamatan Tompaso Kabupaten Minahasa. Jurnal Pembangunan Ekonomi dan Keuangan Daerah (PEKD), 17(1), 1-25

Marwoko,Hari. (2013). Budidaya Tanaman Pangan. Singkawang. Maraga Borneo Tarigas PT.

Noviana S, Endang (2003). Analisis Efisiansi Usaha tani Jagung Manis (Zea Mays Saccharata Sturt) (Studi Kasus di Desa Pandanrejo Kecamatan Bumiaji Kota Batu),. Univ. Muhamadiah, Malang.

Pata, A.A. (2011). Analisis pendapatan dan kelayakan usaha tanaman tomat. Jurnal Vegeta, $5(1), 56-62$

Romadi. (2010). Penelusuran arsip dan sumber lisan dalam rangka menyusun sejarah desa bagi perangkat desa dan anggota BPD Desa Bocor Kecamatan Buluspesantren Kab Kebumen. Jurnal Abdimas, 14(1), 1-6 
AGRONU: JURNAL AGROTEKNOLOGI

Analisis Usaha Tani Budidaya Tanaman Jagung Di Desa Bocor, Kecamatan Buluspesantren Kabupaten Kebumen Vol. 01 No.01 2022 E-ISSN: 0000-0000

Program Studi Agroteknologi, Universitas Ma'arif Nahdlatul Ulama Kebumen Suratiyah, K. (2006). Ilmu Usaha tani. Penebar Swadaya. Jakarta.

Yusmini, Jum'atri Yusri. (2012). Analisis Usaha tani Jagung (Zea mays). 14. Samosir. 